\title{
Changes in carbon stocks in Eucalyptus globulus Labill. plantations induced by different water and nutrient availability
}

\author{
M.V. Madeira ${ }^{a}{ }^{*}$, A. Fabião ${ }^{a}$, J.S. Pereira ${ }^{a}$, \\ M.C. Araújo ${ }^{\mathrm{b}}$, C. Ribeiro ${ }^{\mathrm{c}}$ \\ ${ }^{a}$ Instituto Superior de Agronomia, Tapada da Ajuda, P-1349-017 Lisbon, Portugal \\ ${ }^{\mathrm{b}}$ Störa Enso Pulp, Celbi (Celulose Beira Industrial) S. A., P-3081-853 Leirosa, Portugal \\ ${ }^{\mathrm{c}}$ Escola Superior Agrária de Coimbra, Bencanta, P-3040-316 Coimbra, Portugal
}

\begin{abstract}
Changes in the carbon stocks under different soil water and nutrient conditions were studied in Eucalyptus globulus Labill. stands in a field experiment, at Óbidos (central Portugal). The treatments were irrigation plus a complete fertiliser solution to simulate 'near optimal' nutrition (IF), irrigation only (I), and fertilisers added to rain-fed plots (F). The control (C) received neither water nor fertilisers (except a small amount at planting). The production of biomass (aboveground), the litterfall and the soil chemical composition were evaluated regularly during the experiment. Root biomass was estimated at the end of the experiment. Carbon in biomass, litterfall and soil, increased significantly when water and/or nutrients were supplied, in comparison to the control. The amount of carbon accumulated in the system, 6 years after planting, was 8.22, 10.22, 11.23 and $13.76 \mathrm{~kg} \mathrm{C} \mathrm{m}^{-2}$ in the control, F, I and IF treatments, respectively. The increase of carbon in the system during the same period was 5.86, 7.86, 8.87 and $11.40 \mathrm{~kg} \mathrm{C} \mathrm{m}^{-2}$ in the control, F, I and IF treatments, respectively. This rise in carbon resulted from the accumulation of long-lived woody biomass, which represented between 77.7 (in IF) and 82.9\% (in the control) of the total rise in carbon. Although water was the main limiting factor for biomass accumulation, the allocation of carbon to the soil was mainly related to nutrient supply, irrespective of water availability. The amount of carbon stored belowground, i.e. soil and forest floor, plus stumps and roots, reached 4.2, 4.7, 4.8 and $6.3 \mathrm{~kg} \mathrm{C} \mathrm{m}^{-2}$ in the control, F, I and IF treatments, respectively. The increase in $\mathrm{C}$ in the mineral soil regarding the initial state was, in the same order as above, $0.21,0.75,0.58$ and $1.21 \mathrm{~kg} \mathrm{C} \mathrm{m}^{-2}$. These values were 3.6, 9.6, 6.6 and $10.6 \%$ of the $\mathrm{C}$ accumulated in the whole system, during the experimental period.
\end{abstract}

(C) 2002 Elsevier Science B.V. All rights reserved.

Keywords: Carbon stocks; Eucalyptus globulus; Nutrients; Soil; Water

\section{Introduction}

According to the Kyoto Protocol, forests may be used by the industrialised countries to meet their commitment to reduce greenhouse gas emissions by

\footnotetext{
* Corresponding author.

E-mail addresses: aa15309@isa.utl.pt (M.V. Madeira),

clara-araujo@storaenso.com (M.C. Araújo).
}

5\% below the 1990 level, within the commitment period of 2008-2012. Forests have an important role to play in the carbon cycle, as defined in a recent IPCC report (Watson et al., 2000). Despite progress in the quantification of the carbon balance of forests, major uncertainties remain in relation to the importance and behaviour of soil carbon stocks (Malhi et al., 1999).

The role and the importance of forests as sources or sinks for carbon are likely to be quite variable with 
region, type of forest and age of the trees. Forest plantations have been considered as potential fast response carbon sinks that may play a role in temporarily storing some of the carbon emitted. In spite of the controversy about the characterisation and the definition of the activities of "afforestation, reforestation and deforestation" (WBGU, 1998), it is obvious that a large proportion of the Eucalyptus globulus Labill. plantations in Portugal may be considered as the so-called "Kyoto forests", i.e. areas submitted to afforestation or reforestation since 1990, and therefore qualifying as potential carbon sinks. The area planted with eucalypt in Portugal has increased from $438 \times 10^{3}$ ha in 1992 (Divisão de Inventário Florestal, $1994)$ to ca. $676 \times 10^{3}$ ha by the end of the decade (Portuguese Forest Service in http://www.dgf.minagricultura.pt). It will be important to know the verifiable changes in carbon stocks over land surfaces in the period 2008-2012 (Watson et al., 2000) and therefore a better understanding is needed on the stores and fluxes of carbon in eucalypt plantations.

Forests accumulate carbon both in biomass and in soil organic matter (Lal et al., 1998), until harvest or disturbance occurs. Plantations may accumulate carbon at a very high rate, especially when composed of fast growing tree species installed on previously agricultural land with low carbon content. The short harvesting rotation of E. globulus (10-12 years) and the use of wood for pulp and paper, however, tend to reduce the importance of those ecosystems in long term carbon sequestration. In that case, soil may be a major storage compartment, if properly managed (Madeira, 1998). Nevertheless, little is known about the rates of accumulation or the fate of carbon in the soil in these forest plantations under Mediterranean climate.

It is likely that the capacity to store carbon in forest plantations will be positively related to primary productivity (NPP), which is usually high in eucalypt plantations. For example Pereira et al. (1994) stated that aboveground NPP varied between ca. 12 and $18 \mathrm{t}$ carbon $\mathrm{ha}^{-1}$ per year in 3-year-old experimental plantations in central Portugal. Productivity was strongly influenced by water and nutrient availability. Madeira and Pereira (1990-1991) and Pereira et al. $(1989,1994)$ noticed that irrigation increased productivity more than nutrient supply without irrigation. The proportion of total carbon allocated to roots is also probably influenced by the water and nutrient status of the soil (Keyes and Grier, 1981; Persson, 1983; Axelsson and Axelsson, 1986; Fabião et al., 1995) and it is likely that root biomass production and fine root turnover strongly influence the amount and dynamics of carbon storage in the soil. Much less is known about these belowground processes than about aboveground biomass accumulation, especially under situations of contrasting availability of water and nutrients.

The objectives of this study were to evaluate the effect of controlled changes in soil nutrients and water availability on biomass production and carbon storage in the soil in an E. globulus plantation and to establish possible limits for the carbon sink capacity of these ecosystems under the Mediterranean type of climate.

\section{Methods}

A field experiment was installed in March 1986 at Quinta do Furadouro (Óbidos, Portugal, $39^{\circ} 20^{\prime} \mathrm{N}$, $9^{\circ} 13^{\prime} \mathrm{W}, 30 \mathrm{~m}$ a.s.l.), about $10 \mathrm{~km}$ from the Atlantic Ocean. The climate is of the Mediterranean type, tempered by an oceanic influence. The 30 -year mean rainfall in the area averages $607 \mathrm{~mm}$, but less than $10 \%$ occurs between May and September (Reis and Gonçalves, 1981). The relative humidity of the air during summer may be as high as $80 \%$ at 9 A.M., and fogs are frequent. The mean annual temperature is $15.2{ }^{\circ} \mathrm{C}$, ranging from a monthly average of 10.4 (January) to $19.8{ }^{\circ} \mathrm{C}$ (August).

The soils are Arenosols (FAO/UNESCO, 1988), with a low clay content (less than $40 \mathrm{~g} \mathrm{~kg}^{-1}$ ) throughout the soil profile (Madeira and Pereira, 1990-1991). Before the experiment was started in 1986, concentrations of organic carbon in the $0-70 \mathrm{~cm}$ layers varied between 2.3 and $2.8 \mathrm{~g} \mathrm{~kg}^{-1}$. Available $\mathrm{K}$ varied between 23 and $31 \mathrm{mg} \mathrm{kg}^{-1}$ and available $\mathrm{P}$ between 8 and $9 \mathrm{mg} \mathrm{kg}^{-1}$ in 0-90 cm of the soil. The sum of exchangeable bases varied between 0.45 and $0.75 \mathrm{cmol}_{\mathrm{c}} \mathrm{kg}^{-1}$ up to $90 \mathrm{~cm}$ depth, and $\mathrm{pH}\left(\mathrm{H}_{2} \mathrm{O}\right)$ values were uniform (5.9-6.3) throughout the soil profile.

The 3-month old E. globulus seedlings were planted at $3 \mathrm{~m} \times 3 \mathrm{~m}$ spacing after the soil was ploughed up to $80 \mathrm{~cm}$ depth. Before planting $1.5 \mathrm{tha}^{-1}$ of dolomitic limestone $\left(66.5 \%\right.$ of $\mathrm{CaCO}_{3}, 32.5 \%$ of $\mathrm{MgCO}_{3}$ ) was applied to the experimental area. Each seedling was supplied at planting with $200 \mathrm{~g}$ of a commercial 
Table 1

Amount of nutrients $\left(\mathrm{kg} \mathrm{ha}^{-1}\right)$ supplied to the different treatments from March 1986 to March $1992^{\mathrm{a}}$

\begin{tabular}{lrrrrr}
\hline Treatments & \multicolumn{1}{c}{$\mathrm{N}$} & \multicolumn{1}{c}{$\mathrm{P}$} & $\mathrm{K}$ & $\mathrm{Ca}$ & $\mathrm{Mg}$ \\
\hline $\mathrm{IF}$ & 952 & 347 & 917 & 3607 & 1164 \\
I & 46 & 26 & 137 & 2375 & 740 \\
F & 734 & 251 & 660 & 1463 & 511 \\
C & 31 & 26 & 41 & 399 & 139 \\
\hline
\end{tabular}

a The treatments were combined irrigation and fertilisation (IF), irrigation (I), solid fertilisation (F), and control (C). See text for explanation of differences between treatments.

fertiliser containing $14.0 \mathrm{~g}$ of $\mathrm{N}, 18.3 \mathrm{~g}$ of $\mathrm{K}$ and $11.6 \mathrm{~g}$ of $\mathrm{P}$.

The experimental design consisted of a control, without fertilisation (except the initial amount supplied to all seedlings) or irrigation and three treatments in $1880 \mathrm{~m}^{2}$ effective measurement plots, replicated in two blocks (Pereira et al., 1989). The treatments were daily irrigation from April to October (I), broadcast application of a pelleted fertiliser in March and October of each year $(\mathrm{F})$ and daily irrigation as in I but combined once a week with application of a liquid fertiliser solution (IF) (Table 1). An additional amount of dolomitic limestone $\left(4 \mathrm{tha}^{-1}\right.$ ) was supplied to the $\mathrm{F}$ and IF treatment plots. Water was supplied to the I and IF treatments using drip tubes placed along the tree rows. Only one-third of the plot area was wetted by the drippers. The amount of water was estimated to maintain at least $80 \%$ of the field capacity in the wetted soil, and fertilisers were supplied to the IF according to the needs to produce new tissues by the trees.

The large amount of $\mathrm{Ca}$ and $\mathrm{Mg}$ supplied to the IF and I treatments (see Table 1) were largely the result of the high concentration of these elements in the irrigation water (Madeira and Pereira, 1990-1991). The different amount of $\mathrm{N}$ supplied to $\mathrm{C}$ and I were due to the fact that irrigation water contained some $\mathrm{N}$. The differences in the amount of nutrients supplied to $F$ and IF resulted both from the influence of irrigation water and from different application rates.

Tree sampling to determine above- and belowground biomass was performed in 1992, i.e. 6 years after planting. Seven trees from each treatment plot of one of the blocks were selected for aboveground biomass measurement as follows: three with DBH equal to the plot mean, two equal to the plot mean minus standard deviation (S.D.), two equal to the plot mean plus S.D. The trees were cut about $10 \mathrm{~cm}$ above the ground, divided into aboveground biomass components (stem with bark, branches and leaves) and weighed. Samples of the biomass components were collected in situ for dry weight determination. Later they were oven-dried at $80-85{ }^{\circ} \mathrm{C}$ and weighed. The dry weight of the components was calculated from total fresh weight of each component and moisture content. The biomass of the components and of the whole aboveground was determined through allometric regressions adjusted with the sample trees and calculated on an area basis from tree dendrometric parameters and actual stand density.

For root mass assessment, an additional tree, with a DBH equal to the treatment mean was selected in each treatment. Trees near clearings or close to other trees exceptionally large or small were excluded. A soil volume corresponding to the average surface area per tree (i.e. $3 \mathrm{~m} \times 3 \mathrm{~m}$ ), centred in the stump, was excavated down to $80 \mathrm{~cm}$ depth, separating the $0-20,20$ 50 and $50-80 \mathrm{~cm}$ layers. Stumps and taproots were extracted independently. The excavated soil was sifted in place through a $5 \mathrm{~mm}$ mesh sieve to separate roots. From the sifted soil of each soil layer, after homogenisation, 24 samples were taken to quantify the amount of fine root fragments not separated by the previous sieving. All samples were sealed in plastic bags and kept frozen until laboratory handling.

The root samples were dry cleaned in the laboratory and sifted through a $2 \mathrm{~mm}$ mesh sieve followed by a $1 \mathrm{~mm}$ mesh sieve whenever needed. They were ovendried at $80-85^{\circ} \mathrm{C}$ and weighed. The samples from the soil fraction discarded during the field sieving were dry sifted through a $1 \mathrm{~mm}$ mesh sieve to recover the remaining fine roots. These were handled as above, and an average correction factor for fine root biomass was calculated for each treatment.

Litterfall was estimated monthly during 5 years (from April 1987 to the beginning of March 1992) from the catch of residues in 20 litter traps, located at random in each treatment (10 in each plot) in the subplots used only for non-destructive measurements. The litter layer of the forest floor was sampled ca. 6 years after planting (beginning March 1992) using square wooden frames, $50 \mathrm{~cm} \times 50 \mathrm{~cm}$. The 15 replicates were taken from each treatment. The litterfall and the litter layer were quantified as dry mass (80$85^{\circ} \mathrm{C}$ ) on an area basis. 
The samples of litter layer and roots were ground in a laboratory mill to a particle size $<1 \mathrm{~mm}$. The ash content of root and litter layer samples was determined by dry combustion for $6 \mathrm{~h}$ at $450{ }^{\circ} \mathrm{C}$ and the belowground biomass and the litter layer mass data were expressed on an ash-free basis, to eliminate the effect of remaining soil particles (Persson, 1990). The ashfree belowground biomass was expressed on an area basis from tree density.

Soil samples for organic carbon determination were taken with a corer ( $5 \mathrm{~cm}$ internal diameter) along the tree rows of the treatments, at least $50 \mathrm{~cm}$ away from the tree trunks. In I and IF treatments samples were also taken along the middle distance between tree rows, i.e. in an area not affected by dripping irrigation. The soil cores were sampled at $10 \mathrm{~cm}$ intervals up to $60 \mathrm{~cm}$ depth. Undisturbed soil samples to measure soil bulk density were taken from the walls of the pit excavated in each treatment for root mass assessment. From each layer $(0-10,10-20,20-40$ and $40-60 \mathrm{~cm})$ eight samples were taken.

Soil bulk density was determined after drying (100$105{ }^{\circ} \mathrm{C}$ ) undisturbed soil samples. Whole soil samples were air dried and forced through a $2 \mathrm{~mm}$ sieve prior to chemical analysis, after discarding roots. The nonhumified organic matter fraction was separated by a $50 \mathrm{~mm}$ sieve following the methodology described by Bruckert (1979). The organic carbon in both the bulk samples and the non-humified organic matter fraction was determined by wet oxidation according to the method described by De Leenheer and Van Hove (1958).

The carbon amount of the aboveground biomass and litterfall were calculated assuming an average carbon content of 50\%. Those amounts in litter layer and belowground biomass were calculated in a similar way, on the respective ash-free mass. The amount in the soil was calculated as the product between carbon concentration and soil mass, taking into account the bulk density values.

The treatments were compared in terms of carbon contents in the biomass, litterfall and litter layers, using analysis of variance and Duncan's new multiple range test for mean separation analysis. The Tukey test was used to compare the values of soil bulk density, as well as the carbon concentration in soil as a whole and the concentration in the non-humified organic matter fraction. Belowground biomass was not subjected to statistical analysis because only one tree per treatment was sampled.

\section{Results and discussion}

\subsection{Carbon in the biomass}

The carbon accumulated in total standing biomass (above- plus belowground) 6 years after planting, ranked as IF $>$ I $>$ F $>$ C (Table 2; Fig. 1). The total biomass in treatment IF $\left(9.71 \mathrm{~kg} \mathrm{C} \mathrm{m}^{-2}\right)$ was $1.2,1.4$ and 1.8 times higher than in $\mathrm{I}, \mathrm{F}$ treatments and control, respectively. The carbon accumulated in either below- or aboveground biomass followed the same ranking (Fig. 1). The shoot/root ratio, however, ranked differently from total biomass, with the highest value in the irrigated treatment (I) and the lowest in the control (Table 2). It is well known that moderate soil water deficits may increase the relative rate of carbon allocation to roots in detriment of the aboveground biomass (Pereira and Chaves, 1995), however the low shoot/root ratio in IF may be the result of high nutrient availability counteracting the effects of water supply alone. The proportions of carbon in standing above-

Table 2

Average above- and belowground biomass, accumulated litterfall over the experimental period and forest floor litter layer at the end of the experiment expressed as the total amount of carbon per square meter, 6 years after planting ${ }^{\mathrm{a}}$

\begin{tabular}{llllll}
\hline Treatment & \multicolumn{2}{l}{ Amount of carbon $\left(\mathrm{kg} \mathrm{C} \mathrm{m}^{-2}\right)$} & \multicolumn{2}{c}{ Shoot/root ratio } \\
\cline { 2 - 5 } & Aboveground & Belowground & Accumulated litterfall & Forest floor litter \\
\hline C & $4.03 \mathrm{a}$ & 1.34 & $0.58 \mathrm{a}$ & $0.28 \mathrm{a}$ & 3.01 \\
F & $5.53 \mathrm{~b}$ & 1.29 & $0.72 \mathrm{ab}$ & $0.29 \mathrm{a}$ & 4.29 \\
I & $6.45 \mathrm{c}$ & 1.52 & $0.77 \mathrm{~b}$ & $0.32 \mathrm{a}$ & 4.24 \\
IF & $7.50 \mathrm{~d}$ & 2.21 & $1.05 \mathrm{~b}$ & $0.48 \mathrm{~b}$ & 3.39 \\
\hline
\end{tabular}

${ }^{\text {a }}$ The treatments are as in Table 1 . Values followed by different characters within a column were statistically different $(P<0.05)$. 




Fig. 1. Carbon in aboveground (AGC) and belowground (BGC) biomass components according to treatments. C: control; F: fertilised; I: irrigated; IF: irrigated and fertilised. Stump was included in the tap root fraction.

(75-81\%) and belowground (19-25\%) biomass were similar to those reported by Keith et al. (1997) for a mature Eucalyptus pauciflora forest in Australia.

Treatment effects on biomass production resulted mostly from differences in the woody (perennial) components, i.e. stem (wood and bark) and stump plus taproot (Fig. 1). The proportion of aboveground carbon allocated to stemwood plus bark ranked IF $>$ I $>$ $\mathrm{F}>$ C. A similar trend was found for the proportion of belowground carbon allocated to the stump plus taproot. These results suggest that abundance of nutrients and water in the soil increased the proportion of carbon allocated to the perennial components of the trees.

\subsection{Carbon in litterfall and forest floor}

The amount of carbon in litterfall collected along the 6 years of the experiment ranked as IF $>$ I $>$ $\mathrm{F}>\mathrm{C}$ (Table 2). In the IF treatment the amount $\left(1.05 \mathrm{~kg} \mathrm{C} \mathrm{m}^{-2}\right)$ was $1.4,1.5$ and 1.8 times higher than in I, F treatments and control, respectively. All these values are higher than those reported by Fabião (1986) for plantations of the same age, in the region $\left(0.43 \mathrm{~kg} \mathrm{C} \mathrm{m}^{-2}\right)$.
The amount of carbon in the forest floor at the end of the experiment was significantly higher in IF treatment $\left(0.48 \mathrm{~kg} \mathrm{C} \mathrm{m}^{-2}\right)$ than in the other treatments and the control (Table 2). The proportion of the litterfall carbon remaining in the litter layer at the end of the experiment was similar $(0.46,0.42,0.41$ and 0.48 in IF, I, F and C, respectively). This suggests that rates of carbon loss from litterfall, were independent of treatment. Such a trend is in agreement with the results of leaf litter decomposition reported by Ribeiro et al. (in this issue).

\subsection{Carbon in the mineral soil}

The concentration of organic carbon in the mineral soil of the control did not differ from the initial value and was uniform throughout the soil profile 6 years after planting (Table 3 ). In the irrigated treatments, the areas influenced by dripping (Ir and IFr) had higher carbon concentration than the soil of the rain-fed treatments, or the soil not influenced by dripping (Ibr and IFbr). In the top soil layer $(0-10 \mathrm{~cm})$ the carbon concentration of rain-fed treatments was significantly lower than that of irrigated treatments. The 
Table 3

Concentrations $\left(\mathrm{g} \mathrm{kg}^{-1}\right)$ of organic carbon in soil before treatments (BT) and according to treatments and soil depth at the end of the experiment $^{\mathrm{a}}$

\begin{tabular}{|c|c|c|c|c|c|c|c|}
\hline \multirow[t]{2}{*}{ Soil depth $(\mathrm{cm})$} & \multirow[t]{2}{*}{ BT } & \multicolumn{6}{|l|}{ Treatments } \\
\hline & & $\mathrm{C}$ & $\mathrm{F}$ & Ir & $\mathrm{Ibr}$ & IFr & IFbr \\
\hline $0-10$ & $2.50 \pm 0.47 \mathrm{a}$ & $2.49 \pm 0.55 \mathrm{a}$ & $4.41 \pm 1.88 \mathrm{a}$ & $9.47 \pm 3.21 \mathrm{~b}$ & $2.43 \pm 0.51 \mathrm{a}$ & $7.93 \pm 3.02 b$ & $3.05 \pm 0.49 \mathrm{a}$ \\
\hline $10-20$ & $2.80 \pm 0.55 \mathrm{ac}$ & $2.60 \pm 0.54 \mathrm{ac}$ & $3.64 \pm 1.37 \mathrm{ab}$ & $4.41 \pm 1.03 \mathrm{bd}$ & $2.21 \pm 0.70 \mathrm{c}$ & $5.65 \pm 2.23 \mathrm{~d}$ & $3.21 \pm 0.52 \mathrm{abc}$ \\
\hline $20-30$ & $2.60 \pm 0.61 \mathrm{ab}$ & $2.85 \pm 1.46 \mathrm{ab}$ & $3.47 \pm 0.92 \mathrm{ab}$ & $3.75 \pm 1.37 \mathrm{a}$ & $2.24 \pm 0.78 b$ & $5.49 \pm 2.18 \mathrm{c}$ & $3.05 \pm 0.68 \mathrm{ab}$ \\
\hline $30-40$ & $2.50 \pm 0.71 \mathrm{a}$ & $2.97 \pm 1.20 \mathrm{a}$ & $3.09 \pm 1.10 \mathrm{a}$ & $3.15 \pm 1.33 \mathrm{ab}$ & $2.50 \pm 0.70 \mathrm{a}$ & $4.27 \pm 1.06 \mathrm{~b}$ & $3.46 \pm 1.08 \mathrm{ab}$ \\
\hline $40-50$ & $2.30 \pm 0.59 \mathrm{a}$ & $2.81 \pm 1.01 \mathrm{a}$ & $2.85 \pm 0.95 \mathrm{a}$ & $2.87 \pm 0.93 \mathrm{a}$ & $2.40 \pm 0.88 \mathrm{a}$ & $3.52 \pm 1.37 \mathrm{a}$ & $3.19 \pm 1.13 \mathrm{a}$ \\
\hline $50-60$ & $2.30 \pm 0.73 \mathrm{a}$ & $2.39 \pm 0.70 \mathrm{a}$ & $2.44 \pm 0.91 \mathrm{a}$ & $2.61 \pm 0.87 \mathrm{a}$ & $2.41 \pm 0.70 \mathrm{a}$ & $3.79 \pm 1.38 \mathrm{a}$ & $3.03 \pm 0.58 \mathrm{a}$ \\
\hline
\end{tabular}

${ }^{\text {a }}$ The treatments are as in Table 1. $r$ : along tree rows and dripping tubes; br: between tree rows, in the area not influenced by dripping tubes. Values for each depth followed by different characters were statistically different $(P<0.05)$.

top soil of the wetted areas showed higher concentration in I than in IF. The decrease of this concentration with depth was, however, more pronounced in the former. The carbon concentration in the $50-60 \mathrm{~cm}$ layer was well above the initial value in IF, whereas this was not true for treatment I. In the areas of the treatments I and IF not affected by irrigation, the organic carbon concentration did not vary with depth and did not differ from the initial value (Table 3 ).

A high proportion of the carbon stored in the surface layers of mineral soil was in the non-humified organic matter fraction, especially in the areas influenced by dripping, i.e. along tree rows of treatments I and IF (Table 4). Indeed, the non-humified carbon concentration increased eight and six times in Ir and Ifr, respectively, in relation to the control, whereas total carbon concentration increased only 3.8 and 3.2 times. In the $\mathrm{F}$ treatment, the non-humified carbon and the total carbon concentrations increased only 2.1 and 1.8 , respectively, times relative to the control. The nonhumified carbon fraction expressed as a percentage of total organic carbon followed approximately the variation of the concentration of non-humified fraction of carbon $\left(R^{2}=0.94, P<0.001\right)$, as found by Nyborg et al. (1998). This agrees with the hypothesis that the enhancement of carbon concentration in the soil may result from its inputs through fine root production, especially in the areas influenced by irrigation or fertiliser amendment, as shown by Janzen et al. (1997) and Turner and Lambert (2000).

The concentration of total organic carbon in the top soil $(0-10 \mathrm{~cm}) 6$ years after planting increased 1.8 , 3.8, and 3.2 times in F, and wetted areas of I and IF treatments, respectively, relative to the initial value (Table 3). In the control the $\mathrm{C}$ concentration was similar to the initial value. This initial carbon concentration was much lower than that determined by Fabião et al. (1997) in the $0-10 \mathrm{~cm}$ soil of E. globulus plantations of 18 years old $\left(25 \mathrm{~g} \mathrm{C} \mathrm{kg}^{-1}\right)$ and 12 years old $\left(21 \mathrm{~g} \mathrm{C} \mathrm{m}^{-2}\right)$, in the same region. These data suggest a high potential for carbon storage in soils of forest plantations in the region (Madeira, 1998). The data also stress that, in the absence of nutrients and water supply (or both), e.g. the control, the increment in organic carbon in the mineral soil may be a slow process, as reported by Fisher and Binkley

Table 4

Organic carbon in mineral soil $\left(\mathrm{g} \mathrm{kg}^{-1}\right)$ corresponding to the non-humified organic matter fraction at the end of the experimental period ${ }^{\mathrm{a}}$

\begin{tabular}{lllllll}
\hline Soil depth $(\mathrm{cm})$ & \multicolumn{2}{l}{ Treatments } & & & \\
\cline { 2 - 7 } & $\mathrm{C}$ & F & Ir & Ibr & IFr & IFbr \\
\hline $0-10$ & $0.80 \pm 0.35 \mathrm{a}$ & $1.69 \pm 0.62 \mathrm{a}$ & $6.30 \pm 1.90 \mathrm{~b}$ & $0.80 \pm 0.30 \mathrm{a}$ & $4.80 \pm 2.00 \mathrm{~b}$ & $1.05 \pm 0.35 \mathrm{a}$ \\
$10-20$ & $0.74 \pm 0.29 \mathrm{a}$ & $1.00 \pm 0.32 \mathrm{a}$ & $2.05 \pm 0.60 \mathrm{~b}$ & $0.60 \pm 0.20 \mathrm{a}$ & $2.69 \pm 0.80 \mathrm{~b}$ & $0.90 \pm 0.50 \mathrm{a}$ \\
\hline
\end{tabular}

\footnotetext{
${ }^{\text {a }}$ Treatments were described in the legend of Table 3. Values for each depth followed by different characters were statistically different $(P<0.05)$.
} 
(2000) and Turner and Lambert (2000). Madeira et al. (2002) also reported a slow increase in total organic carbon concentration (from 12.5 to $14.4 \mathrm{~g} \mathrm{~kg}^{-1}$ ) in the $0-10 \mathrm{~cm}$ soil of an E. globulus plantation of high productivity (ca. $23 \mathrm{~m}^{3} \mathrm{ha}^{-1}$ per year), during a 10year period.

The differences in organic carbon concentrations in the soil from fertiliser and water application treatments correlated well with the amount of fine roots determined by Fabião et al. (1995) and Kätterer et al. (1995). In fact, in the control and in areas not directly influenced by irrigation (i.e. between tree rows) of the I and IF treatments, where the increase of carbon concentration was negligible, the amount of fine roots in the $0-20 \mathrm{~cm}$ soil depth was similar (23.3$36.1 \mathrm{~g} \mathrm{~m}^{-2}$ ). In treatment $\mathrm{F}$, however, there were higher amount of roots $\left(42.2 \mathrm{~g} \mathrm{~m}^{-2}\right)$ which were associated with a clear increase of organic carbon concentration. The augmentation of carbon concentration in the areas influenced by irrigation of I and IF was paralleled by the presence of high amount of fine roots (61.1-94.4 $\mathrm{g} \mathrm{m}^{-2}$ ) in 0-20 cm of depth (Fabião et al., 1995; Kätterer et al., 1995).

The difference between IF and I in carbon concentration in the topsoil $(0-10 \mathrm{~cm})$, which was negligible at 2.5 and 4.5 years after planting, increased with time. This may be explained by the higher root counts in the top soil of I treatment than in that of the IF, as reported by Kätterer et al. (1995). Similarly, the higher concentration of carbon in the soil profile (below $10 \mathrm{~cm}$ soil depth) of IF than of I may be related to the higher fine root counts in the former (Kätterer et al., 1995). This suggests that the higher concentration of nutrients in IF (Madeira and Pereira, 1990-1991) might have led to a deeper root distribution and an increase in carbon accumulation at deeper depths. Low nutrient availability in I could explain the low amount of fine roots in the deeper soil layers and their greater abundance in the topsoil, where nutrients released from decomposing litter are available.

Six years after planting, the carbon content in the soil $(0-60 \mathrm{~cm}$ depth) increased in all the treatments (Fig. 2). The differences in organic carbon content between treatments resulted from differences in carbon concentration, as soil bulk density values were similar in all treatments to $60 \mathrm{~cm}$ depth (Table 5). In the control, the increase in carbon content relative to the initial content was $0.213 \mathrm{~kg} \mathrm{C} \mathrm{m}^{-2}$. In $\mathrm{F}$ the increment was higher $\left(0.754 \mathrm{~kg} \mathrm{C} \mathrm{m}^{-2}\right)$ than in control, as well as in I treatment $\left(0.582 \mathrm{~kg} \mathrm{C} \mathrm{m}^{-2}\right)$. The increment in carbon content in $\mathrm{F}$ was of the same magnitude as that reported by Madeira et al. (2002) in a highly productive E. globulus plantation. The IF treatment showed the highest increment of carbon

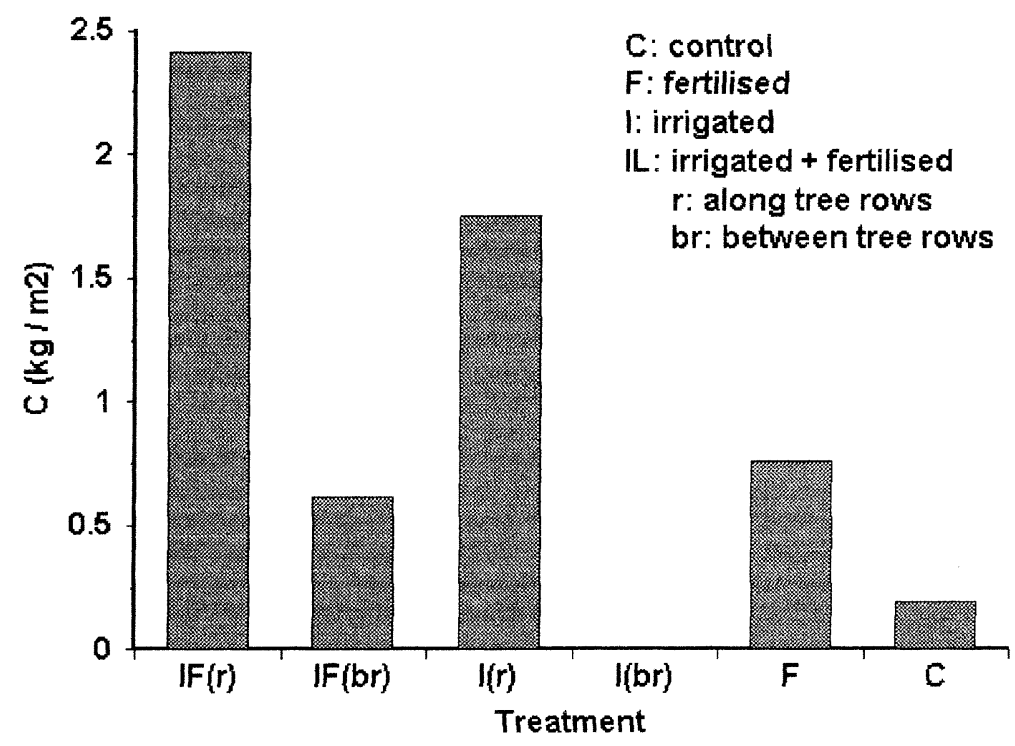

Fig. 2. Increment of organic carbon in the soil up to $60 \mathrm{~cm}$ depth according to treatment, at the end of the experiment. 
Table 5

Bulk density values $\left(\mathrm{g} \mathrm{cm}^{-3}\right)$ of soil according to treatments at the end of the experiment ${ }^{\mathrm{a}}$

\begin{tabular}{|c|c|c|c|c|}
\hline \multirow[t]{2}{*}{ Depth (cm) } & \multicolumn{4}{|l|}{ Treatments } \\
\hline & $\mathrm{C}$ & $\mathrm{F}$ & I & IF \\
\hline $0-10$ & $1.54 \pm 0.06$ & $1.55 \pm 0.04$ & $1.55 \pm 0.07$ & $1.53 \pm 0.07$ \\
\hline 10-20 & $1.53 \pm 0.07$ & $1.48 \pm 0.05$ & $1.50 \pm 0.06$ & $1.53 \pm 0.04$ \\
\hline $20-40$ & $1.56 \pm 0.07$ & $1.52 \pm 0.07$ & $1.57 \pm 0.05$ & $1.54 \pm 0.06$ \\
\hline $40-60$ & $1.66 \pm 0.04$ & $1.64 \pm 0.04$ & $1.66 \pm 0.05$ & $1.63 \pm 0.05$ \\
\hline
\end{tabular}

${ }^{\text {a }}$ Treatments are described in Table 1 . Values were not statistically different $(P>0.05)$.

(1.208 $\mathrm{kg} \mathrm{C} \mathrm{m}^{-2}$ ), which was twice the value in I. The increment in wetted areas of I and IF treatments was obviously much higher than in the non-wetted (Fig. 2). The increase in the carbon content in IF may be higher than determined in this study because the concentration at 50-60 cm depth was still higher than the initial value (Table 3 ).

The increment of carbon content in the soil per unit of $\mathrm{N}$ fertiliser applied, was the highest in I, followed by the control (126.5 and $68.7 \mathrm{~kg} \mathrm{C}$ per $\mathrm{kg} \mathrm{N}$, respectively), i.e. the treatments with low inputs of $\mathrm{N}$. The treatments with fertiliser amendments had much lower $\mathrm{N}$ efficiencies: 12.6 and $10.3 \mathrm{~kg} \mathrm{C}$ per $\mathrm{kg} \mathrm{N}$ in IF and $\mathrm{F}$, respectively. This parallels what happened with aboveground biomass where abundant water and low $\mathrm{N}$ supply (as in I) increased the aboveground $\mathrm{N}$ use efficiency (calculated as the ratio of aboveground $\mathrm{NPP} /$ mass of $\mathrm{N}$ in the biomass at the time of harvest) in comparison to the other treatments, namely those with fertilisers added (Pereira et al., 1994).

Fertiliser application enhanced carbon storage in the soil both in rain-fed and irrigated plots as was reported for other systems (Janzen et al., 1997). The net gain of carbon in treatment $\mathrm{F}$ with respect to the control 6 years after planting was $0.541 \mathrm{~kg} \mathrm{C} \mathrm{m}^{-2}$ (Fig. 2). This gain in carbon corresponds to an accumulation of $7.7 \mathrm{~kg}$ of $\mathrm{C}$ for each additional kilogram of $\mathrm{N}$ applied to $\mathrm{F}$. The net gain in IF with respect to I was $0.626 \mathrm{~kg} \mathrm{C} \mathrm{m}^{-2}$, which corresponds to an accumulation of $6.9 \mathrm{~kg}$ of $\mathrm{C}$ per additional kilogram of $\mathrm{N}$ applied to IF, regarding to I. It is likely that the influence of nutrient application may decrease at later stages of forest development, as reported by Keith et al. (1997) and Canary et al. (2000) for mature stands, where the application of $\mathrm{N}$ or $\mathrm{P}$ did not have significant effects on the increment of soil organic content.

\subsection{Distribution of carbon in the whole system}

The increment of carbon in the whole system followed the same pattern of variation with treatments as the biomass (Table 6). The distribution between compartments was not the same in all treatments. For example, there was a lower proportion of carbon in the forest floor and belowground (roots and soil organic matter) in I ( $42.5 \%$ of the total in the system) than in the control (50.9\%) (Table 7). Overall these values are lower than those of mature forests (56 and 89\% in temperate and boreal forests, respectively) as reported by Malhi et al. (1999). They are also lower than those found in a mature forest of E. pauciflora in Australia, under a climate cooler than our experimental conditions, where the carbon stored belowground up to $1 \mathrm{~m}$ of depth was $77 \%$ of total in the system (Keith et al., 1997).

Estimates of belowground carbon in Portuguese eucalypt plantations indicated values higher than those found in our experiment. The amount of carbon stored belowground up to $60 \mathrm{~cm}$ depth in a 7-year-old $E$. globulus plantation in a Cambisol in southern Portugal, was $4.84 \mathrm{~kg} \mathrm{C} \mathrm{m}^{-2}$, i.e. $54.5 \%$ of the total (Cortez, 1996). In an 18-year-old E. globulus plantation grown on a Cambisol near our experimental area

Table 6

Amount of carbon in whole system 6 years after planting, and the increase of carbon in system during the experimental period (the treatments are as in Table 1)

\begin{tabular}{llrrl}
\hline Carbon $\left(\mathrm{kg} \mathrm{m}^{-2}\right)$ & \multicolumn{4}{l}{ Treatments } \\
\cline { 2 - 5 } & $\mathrm{C}$ & \multicolumn{1}{l}{$\mathrm{F}$} & \multicolumn{1}{l}{$\mathrm{I}$} & \multicolumn{1}{l}{ IF } \\
\hline Total in the system & 8.22 & 10.22 & 11.23 & 13.76 \\
Rise in the system & 5.86 & 7.86 & 8.87 & 11.40 \\
\hline
\end{tabular}


Table 7

Proportion (\%) of total organic carbon partitioned to the system components (CT) at the end of the experiment, and the distribution of the increment of carbon in the system components (IC) (treatments are as described in Table 1)

\begin{tabular}{|c|c|c|c|c|c|c|c|c|}
\hline \multirow[t]{3}{*}{ System component } & \multicolumn{8}{|c|}{ Treatments } \\
\hline & \multicolumn{2}{|l|}{$\mathrm{C}$} & \multicolumn{2}{|l|}{$\mathrm{F}$} & \multicolumn{2}{|l|}{ I } & \multicolumn{2}{|l|}{ IF } \\
\hline & CT & IC & $\mathrm{CT}$ & IC & $\mathrm{CT}$ & IC & $\mathrm{CT}$ & IC \\
\hline Stem + bark & 39.0 & 54.6 & 43.9 & 57.1 & 48.2 & 61.0 & 45.5 & 54.8 \\
\hline Branches & 4.7 & 6.6 & 4.8 & 6.2 & 4.3 & 5.4 & 4.2 & 5.1 \\
\hline Leaves & 5.4 & 7.5 & 5.4 & 7.0 & 5.0 & 6.3 & 4.9 & 5.9 \\
\hline Forest Floor & 3.4 & 4.8 & 2.8 & 3.7 & 2.8 & 3.6 & 3.5 & 4.2 \\
\hline Tap root & 7.9 & 11.1 & 7.1 & 9.3 & 8.0 & 10.1 & 10.0 & 12.0 \\
\hline$>2 \mathrm{~mm}$ roots & 7.5 & 10.6 & 4.6 & 6.0 & 4.5 & 5.7 & 4.8 & 5.8 \\
\hline$<2 \mathrm{~mm}$ roots & 1.0 & 1.3 & 0.9 & 1.1 & 1.0 & 1.2 & 1.2 & 1.5 \\
\hline Soil & 31.1 & 3.6 & 30.5 & 9.6 & 26.2 & 6.6 & 26.0 & 10.6 \\
\hline
\end{tabular}

(Fabião et al., 1997), the carbon belowground up to $60 \mathrm{~cm}$ soil depth was $13.93 \mathrm{~kg} \mathrm{C} \mathrm{m}^{-2}$, which represented $51.8 \%$ of total carbon in the system, assuming that root mass was $20 \%$ of the total biomass. In a nearby 12-year-old plantation on a Podzol, the carbon stored belowground $\left(17.90 \mathrm{~kg} \mathrm{C} \mathrm{m}^{-2}\right.$ ) was about $68 \%$ of the total carbon in the system. On the other hand, this variability points out to the need to consider chronosequences, soil type, forest management and soil conditions before planting, in order to understand the effects of eucalypt plantations on carbon partition between the system components.

The application of water (treatments I and IF) increased the proportion of carbon stored aboveground, mostly as a result of an increase in the proportion of stemwood (Table 7), which may have silvicultural consequences. With the removal of stemwood only, the carbon exported from the system would correspond to 48.2 and $45.5 \%$ in I and IF, respectively. The proportion exported from the control and $\mathrm{F}$ would be, however, much less (39.0 and $43.9 \%$ of total, respectively). If more vegetative components than stemwood would be removed (e.g. whole tree harvesting) the proportions would be 57.5 and $54.6 \%$, and 49.1 and $54.1 \%$, in the same order, i.e. I and IF, and control and $\mathrm{F}$, respectively.

If the carbon increment in the system since planting was taken into account instead of the total amounts, the merchantable timber harvesting would remove the highest proportion from I treatment $(61.0 \%)$, which had the highest shoot/root ratio. The whole tree harvesting would correspond to an higher percentage of carbon removal from the I treatment $(72.7 \%)$ than from the control as well as F and IF treatments (68.7, 70.3 and $65.8 \%$, respectively). This pattern is a result of the higher proportion of carbon being stored in mineral soil of the fertilised treatments $(9.6$ and $10.6 \%$ in F and IF, respectively) as compared to I (6.6\%). The higher proportion of carbon removal through whole tree harvesting in I as compared to the control would result, as for merchantable timber harvesting, from the higher shoot/root ratio in the former.

\section{Conclusions}

1. After 6 years, the increase of $\mathrm{C}$ in mineral soil of the irrigated and fertilised treatment was about six times higher $\left(1.21 \mathrm{~kg} \mathrm{C} \mathrm{m}^{-2}\right)$ than in the control $\left(0.21 \mathrm{~kg} \mathrm{C} \mathrm{m}^{-2}\right)$; the increase of $\mathrm{C}$ in the fertilised $\left(0.75 \mathrm{~kg} \mathrm{C} \mathrm{m}^{-2}\right)$ and in the irrigated $\left(0.58 \mathrm{~kg} \mathrm{C} \mathrm{m}^{-2}\right)$ treatments was intermediate.

2. The increase of carbon in the eucalypt plantation site was proportional to biomass production. Carbon storage was largely associated with biomass accumulation in the perennial woody components.

3. Water was the main factor limiting biomass accumulation, but its effect was much more pronounced for aboveground than for belowground biomass.

4. Allocation of carbon to the mineral soil was enhanced by increasing nutrient supply both in rain-fed and irrigated treatments. 
5. Nitrogen use efficiency in terms of soil carbon accumulation increased with abundant water supply and declined with the addition of fertilisers.

\section{Acknowledgements}

The authors wish to acknowledge the support of Celulose Beira Industrial (CELBI), S. A. The participation of Prof. Sune Linder, Dr. Tom Ericsson, Prof. E. Steen and Dr. T. Kätterer from the SLU, Uppsala, Sweden, in the design of the experiment and parts of the work is gratefully acknowledged. The fieldwork was carried out at CELBI field research site at Quinta do Furadouro, and the laboratory work was conducted at Instituto Superior de Agronomia, Lisbon. Professor Edgar de Sousa is gratefully acknowledged for improving the English style.

\section{References}

Axelsson, E., Axelsson, B., 1986. Changes in carbon allocation patterns in spruce and pine trees following irrigation and fertilization. Tree Physiol. 2, 189-204.

Bruckert, S., 1979. Analyse des complexes organominéreaux des sols. In: Duchanfour, P., Souchier, B. (Eds.), Pédologie. 2. Constituants et Propriétés du Sol. Masson and Cie, Paris, pp. 185-209.

Canary, J.D., Harrison, R.B., Campton, J.E., Chappell, H.N., 2000. Additional carbon sequestration following repeated urea fertilization of second-growth Douglas-fir stands in western Washington. For. Ecol. Manage. 138, 225-232.

Cortez, N., 1996. Compartimentos e Ciclos de Nutrientes em Plantações de Eucalyptus globulus Labill. ssp. globulus e Pinus pinaster Aiton. Doctoral Thesis. Universidade Técnica de Lisboa, Lisboa.

De Leenheer, L., Van Hove, J., 1958. Determination de la teneur en carbone organique des sols. Études critiques des methodes tritrimétriques. Pédologie 8, 39-77.

Divisão de Inventário Florestal, 1994. Actualização do Inventário do Eucalipto, 1992. Estudos e Informação No. 305. Instituto Florestal, Lisboa.

Fabião, A.M.D., 1986. Contribuição para o Estudo da Dinâmica da Biomassa e da Produtividade Primária Líquida em Eucaliptais. Região Litoral do Centro de Portugal. Doctoral Thesis. Universidade Técnica de Lisboa, Lisboa.

Fabião, A., Madeira, M., Steen, E., Kätterer, T., Ribeiro, C., Araújo, C., 1995. Development of root biomass in an Eucalyptus globulus plantation under different water and nutrient regimes. Plant Soil 168-169, 215-223.

Fabião, A., Madeira, M., Steen, E., 1997. Root mass in plantations of Eucalyptus globulus in Portugal in relation to soil characteristics. Arid Soil Res. Rehab. 1, 185-194.
FAO/UNESCO, 1988. Soil Map of the World (Revised Legend). FAO, Rome.

Fisher, F., Binkley, D., 2000. Ecology and Management of Forest Soils, 3rd ed. Wiley, New York.

Janzen, H.H., Campbell, C.A., Gregorich, E.G., Ellert, B.H., 1997. Soil carbon dynamics in Canadian agroecosystems. In: Lal, R.R., Kimble, J.M., Follet, R.F., Stewart, B.A. (Eds.), Soil Processes and the Carbon Cycle. Advances in Soil Science. CRC Press, New York, pp. 57-80.

Kätterer, T., Fabião, A., Madeira, M., Ribeiro, C., Steen, E., 1995. Fine-root dynamics, soil moisture and soil carbon content in a Eucalyptus globulus plantation under different irrigation and fertilisation regimes. For. Ecol. Manage. 74, 1-12.

Keith, H., Raison, R.J., Jacobson, K.L., 1997. Allocation of carbon in a mature eucalypt forest and some effects of soil phosphorus availability. Plant Soil 196, 81-99.

Keyes, M.R., Grier, C.C., 1981. Above- and below-ground net production in 40-year-old Douglas-fir stands on low and high productivity sites. Can. J. For. Res. 11, 599-605.

Lal, R., Kimble, J., Follet, R., 1998. Land use and Soil C pools in terrestrial ecosystems. In: Lal, R.R., Kimble, J.M., Follet, R.F., Stewart, B.A. (Eds.), Management of Carbon Sequestration in Soil. Advances in Soil Science. CRC Press, New York, pp. 1-10.

Madeira, M., 1998. Strategies for rehabilitation of soils in Portuguese forestry systems. Pedon 12, 166-176.

Madeira, M., Pereira, J.S., 1990-1991. Productivity, nutrient immobilisation and soil chemical properties in an Eucalyptus globulus plantation under different water and nutrient regimes. Water Air Soil Pollut. 54, 621-624.

Madeira, M., Azevedo, A., Soares, P., Tomé, M., Araújo, M.C., 2002. Efeitos da lavoura profunda e da gradagem nas características do solo e na produtividade de plantações de Eucalyptus globulus. Rev. Ciên. Agrárias (Abstract in English) 25 (1/2), 158-169.

Malhi, Y., Baldocchi, D.D., Jarvis, P.G., 1999. The carbon balance of tropical, temperate and boreal forests. Plant Cell Environ. 22, 715-740.

Nyborg, M., Molina-Ayala, M., Solberg, E.D., Izaurralde, R.C., Malhi, S.S., Jansen, H.H., 1998. Carbon storage in grassland soils as related to $\mathrm{N}$ and $\mathrm{S}$ fertilizers. In: Lal, R.R., Kimble, J.M., Follet, R.F., Stewart, B.A. (Eds.), Management of Carbon Sequestration in Soil. Advances in Soil Science. CRC Press, New York, pp. 421-432.

Pereira, J.S., Chaves, M.M., 1995. Plant responses to drought under climate change in Mediterranean-type ecosystems. In: Moreno, J.M., Oechel, W.C. (Eds.), Global Change and Mediterraneantype Ecosystems, Ecological Studies, vol. 117. Springer, Berlin, pp. 140-160.

Pereira, J.S., Linder, S., Araújo, M.C., Pereira, H., Ericsson, T., Borralho, N., Leal, L.C., 1989. Optimization of biomass production in Eucalyptus globulus plantations-a case study. In: Pereira, J.S., Landsberg, J.J. (Eds.), Biomass Production by Fast-growing Trees. NATO ASI Series E, Applied Sciences, vol. 166. Kluwer Academic Publishers, Dordrecht, The Netherlands, pp. 101-121.

Pereira, J.S., Madeira, M.V., Linder, S., Ericsson, T., Tomé, M., Araújo, M.C., 1994. Biomass production with optimized 
nutrition in Eucalyptus globulus plantations. In: Pereira, J.S., Pereira, H. (Eds.), Eucalyptus for Biomass Production. The State-of-the-art. CEC/Instituto Superior de Agronomia, Brussels/Lisbon, pp. 13-30.

Persson, H., 1983. The distribution and productivity of fine roots in boreal forests. Plant Soil 71, 87-101.

Persson, H., 1990. Methods of studying root dynamics in relation to nutrient cycling. In: Harrison, A.F., Ineson, P., Heal, O.W. (Eds.), Nutrient Cycling in Terrestrial Ecosystems: Field Methods, Application and Interpretation. Elsevier, London, pp. 198-217.

Reis, R.M., Gonçalves, M.Z., 1981. Caracterização Climática da Região Agrícola do Ribatejo e Oeste. O Clima de Portugal, fasc, vol. XXXII. Instituto Nacional de Meteorologia e Geofísica, Lisboa.
Turner, J., Lambert, M., 2000. Change in organic carbon in forest plantation soils in eastern Australia. For. Ecol. Manage. 133, 231-247.

Watson, R.T., Noble, I.R., Bolin, B., Ravindranath, N.H., Verardo, D.J., Dokken, D.J. (Eds.), 2000. Land use, land-use change, and forestry. Special Report of the Intergovernmental Panel on Climate Change. Cambridge University Press, Cambridge.

WBGU (Wissenschaftlicher Beirat der Bundesregierung Globale Umweltveränderungen), 1998. The accounting of biological sinks and sources under the Kyoto Protocol: a step forwards or backwards for global environmental protection. Sondergutachten 1998. Bremerhaven, Germany (English version). 